\title{
Strategi pemerintahan desa dalam mengembangkan pariwisata
}

\author{
Ristarnado Ristarnado ${ }^{1 *}$, Joko Settyoko $^{2}$, Harpinsyah Harpinsyah $^{3}$ \\ ${ }^{123}$ Fakultas Ilmu Sosial dan Ilmu Politik, Universitas Muara Bungo \\ *Korespondensi Penulis
}

\section{Informasi Artikel Abstrak}

Kata Kunci :
Wisata
Telaga biru
Alam;
Strategi
Pemerintah desa

Histori Artikel :
Wisata merupakan salah satu sector penting dalam peningkatan perekonomian. Di Indonesia sendiri banyak tempat pariwisata yang masih alami namun belum maksimal pengelolaannya. Salah satu wisata tersebut adalah Telaga Biru di Jambi. Penelitian ini bertujuan untuk menganalisis bagaimana strategi pemerintahan Desa Tanjung Alam dalam mengembangkan wisata Telaga Biru. Penelitian ini merupakan penelitian deskriptif kualitatif. Hasil penelitian menunjukkan bahwa terkait dengan dimensi-dimensi strategi yakni: Tujuan, Kebijakan dan Program yang dilakukan Pemerintahan Desa termasuk ke dalam Strategi. Adapun strategi pemerintahan desa Tanjung Alam dalam pengembangan wisata Telaga Biru yaitu penyediaan sarana dan prasarana wisata telaga biru, rencana tambahan promosi, pembentukan pengurus tetap, koordinasi dengan sektor pendukung pariwisata, pelaksanaan promosi pariwisata nusantara terutama di dalam negeri dan pelatihan pemandu wisata. Kendala yang dihadapi pemerintahan desa Tanjung Alam dalam pengembangan wisata Tanjung Alam adalah keterbatasan dana, rendahnya kualitas SDM (sumber daya manusia) pengelola dan Peran Pemerintah Daerah Kabupaten Merangin yang belum aktif dalam mendukung penyediaan sarana dan prasarana kegiatan wisata.

Copyright (C) 2019 Jurnal Politik dan Pemerintahan Daerah 


\section{Pendahuluan}

Indonesia adalah salah satu negara di dunia yang menyimpan banyak potensi alam yang melimpah baik daratan maupun lautan. Berlimpahnya sumber daya alam yang ada dapat meningkatkan pertumbuhan ekonomi ketika sumber daya tersebut dapat di kelola dengan baik sesuai dengan apa yang paling diminati masyarakat sehingga pemanfaatan sumber daya alam tersebut tidak akan menghabiskan waktu ataupun materi akibat ketidakberhasilan dalam mengelola suatu sumber daya. Pariwisata merupakan salah satu pemanfaatan sumber daya alam yang dapat bernilai ekonomi tinggi bagi suatu daerah yang mengelola sumber daya alam menjadi suatu tempat wisata yang dapat menarik pengunjung baik dari dalam maupun dari luar negeri.

Pariwisata merupakan salah satu industri baru yang mampu menyediakan pertumbuhan ekonomi yang cepat dalam hal kesempatan kerja, pendapatan, taraf hidup dan dalam mengaktifkan sektor produksi lain di dalam negara penerima wisatawan. Disamping bernilai ekonomi yang tinggi, pariwisata dapat menumbuhkan dan meningkatkan rasa bangga terhadap bangsa sehingga akan tumbuh masyarakat yang lebih peduli terhadap suatu bangsa. Pariwisata juga sangat potensial untuk membangun dan mengembangkan suatu kawasan, baik di lingkungan perkotaan maupun perdesaan. Selain itu, sektor pariwisata juga memberikan multiplier effect dan nilai manfaat yang besar bagi masyarakat, seperti menciptakan lapangan pekerjaan baru dan menurunkan angka pengangguran.

Dalam era globalisasi sekarang ini, bidang pariwisata merupakan salah satu kegiatan yang mempunyai peranan yang sangat strategis dalam menunjang pembangunan perekonomian nasional. Sektor ini dicanangkan selain sebagai salah satu sumber penghasil devisa yang cukup andal, juga merupakan sektor yang mampu menyerap tenaga kerja dan mendorong perkembangan investasi. Untuk mengembangkan sektor ini pemerintah berusaha keras membuat rencana dan berbagai kebijakan yang mendukung kearah kemajuan sektor ini. Salah satu kebijakan tersebut adalah menggali, menginventarisir dan mengembangkan obyek-obyek wisata yang ada sebagai daya tarik utama bagi wisatawan.

Kabupaten Merangin merupakan salah satu kabupaten di Propinsi Jambi yang memiliki beragam sumber daya alam dan budaya sebagai objek daya tarik wisata. Kabupaten Merangin menjadi salah satu tujuan wisatawan di Provinsi Jambi yang memiliki potensi wisata alam yang sangat indah, baik dari alam maupun budaya dari daerah itu sendiri. Seperti gunung, danau, air terjun, air panas, goa, geopark dan berbagai wisata modern yang kini tengah dikembangkan. Hal ini tentu dapat memberikan kontribusi untuk peningkatan pendapatan daerah melalui kunjungan wisatawan ke sejumlah objek wisata yang ada di sana.

Salah satu objek wisata yang menarik di Kabupaten Merangin yaitu Telaga Biru yang berada di Desa Tanjung Alam Kecamatan Jangkat Timur. Telaga biru ini memberikan sensasi keindahan alam yang khas yaitu warnanya yang biru dan sangat jernih hingga tembus kedasar telaga serta kesejukan udara karena rimbunnya pepohonan disekitar telaga ini. Telaga biru berada diketinggian $2033 \mathrm{Mdpl}$ di kawasan Hutan Produksi Lainnya (HPL) yang berbatasan langsung dengan Taman Nasional Kerinci Seblat (TNKS). Perjalanan menuju telaga biru dapat ditempuh dengan berjalan kaki selama lebih kurang 7 jam atau menggunakan kendaraan roda dua yang hanya memakan waktu 3 jam perjalanan dari desa Tanjung Alam Jangkat Timur. Selama perjalanan mata kita akan disuguhkan dengan pemandangan perbukitan, persawahan yang menghampar luas ditambah bunyi gemercik air dari aliran irigasi sawah serta kebun kopi yang berada disepanjang jalan yang hanya dilengkapi depondok peristirahatan petani yang bisa digunakan oleh wisatawan untuk beristirahat saat hendak mengunjungi telagabiru. Walaupun demikian tidak mudah bagi wisatawan untuk dapat sampai ke Telaga Biru karena perjalanan menembus dalamnya hutan adat dengan jalanan curam, menanjak, menurun, melewati tingginya pepohonan yang dilapisi lumut. 
Pemerintah selaku pejabat yang berwenang harus memberikan perhatian lebih pada objek wisata yang berpotensial menghasilkan pendapatan dan mengarahkan sektor ini sebagai investasi yang menguntungkan kedepannya serta memberikan asumsi yang baik bagi para wisatawan dalam kemudahan prosedur untuk mengikat daya tarik. Namun tidak hanya pendapatan bagi pemasukan pemerintah tapi juga kesejahteraan untuk masyarakat di sekitar objek wisata. Penanganan objek wisata pada peningkatan sumberdaya manusia yang memadai secara konsisten, menyeluruh, terpadu dan sistematis oleh Pemerintah kepada masyarakat perlu dilakukan karena keberhasilan upaya-upaya strategi pengembangan dan pengelolaan kegiatan pariwisata merupakan suatu tindakan, baik itu tindakan pemerintah, swasta maupun masyarakat sehingga terciptanya kerjasama yang baik dan harmonis dan mewujudkan sapta pesona.

Keberadaan sektor pariwisata dalam suatu wilayah dapat memberikan dampak positif maupun negatif. Namun, pada dasarnya tergantung pada manajemen dan tata pengelolaan kepariwisataan yang diperankan oleh segenap pemangku kepentingan (stakeholders) baik dari unsur pemerintahindustri masyarakat yang ada pada wilayah tersebut. Pencapaian tujuan dan misi pembangunan kepariwisataan yang baik, berkelanjutan (sustainable tourism) dan berwawasan lingkungan hanya akan dapat terlaksana manakala dalam proses pencapaiannya dapat dilakukan melalui tata kelola kepariwisataan yang baik (good tourism governance).

Undang-Undang mengenai Otonomi Daerah telah disyahkan pemerintah dengan persetujuan DPR RI, pada tanggal 4 Mei 1999, dan mulai diberlakukan secara efektif pada tahun 2001. Untuk merealisasikan Undang-Undang Otonomi Daerah tersebut, Departemen Dalam Negeri telah mengeluarkan buku pedoman tentang Visi, Misi, Strategi dan Kebijakan Pemberdayaan Masyarakat Desa, sebagai pegangan bagi aparat pemerintah di daerah. Menurut pedoman tersebut, pada pokoknya pemberdayaan masyarakat mempunyai dua makna pokok, yaitu :

1. Meningkatkan kemampuan masyarakat melalui pelaksanaan berbagai kebijakan program pembangunan.

2. Meningkatkan kemandirian masyarakat melalui pemberian wewenang secara proporsional kepada masyarakat dalam mengambil keputusan. Dari penjelasan tersebut, jelas masyarakat diberi kesempatan penuh dalam perencanaan dan pelaksanaan pembangunan. Disitu ditegaskan bahwa tugas birokrasi di daerah hanyalah sebagai fasilitator (pelayanan). Kreativitas masyarakat dipacu dan didorong berkembang. Kemudian Departemen Pariwisata dalam kiprah memberdayakan masyarakat desa telah menyusun program pembangunan desa.

Dihubungkan dengan pedoman Visi, Misi, Strategi dan Kebijakan Pemberdayaan Masyarakat desa tersebut di atas, pembangunan desa wisata ini nampaknya sangat relevan dengan pedoman tersebut. Dengan demikian pembangunan desa wisata dapat dikatakan merupakan tindak lanjut dari pelaksanaan Undang-Undang Otonomi Daerah.

Untuk semakin mewujudkan semangat otonomi daerah hingga pada level pemerintahan desa dan untuk mengatasi berbagai permasalahan yang terjadi dalam wilayah desa dan mewujudkan kemandirian serta kesejahteraan bagi wilayah desa maka pemerintah pada Tahun 2014 mengeluarkan kebijakan perundang-undangan baru yaitu Undang-Undang Nomor 6 Tahun 2014 tentang Desa. Munculnya undang-undang desa tersebut semakin memberi keleluasaan kepada desa untuk melakukan perencanaan, pengawasan, pengendalian dan mengevaluasi kebijakan-kebijakan yang dikeluarkan oleh desa.

Dari uraian diatas perlu disadari oleh pemerintah daerah terutama pemerintah desa Tanjung Alam yang berperan penting dalam mengembangkan desa sehingga dapat mengangkat ekonomi desa apabila setiap obyeknya dikelola dengan baik oleh pemerintah maupun pihak-pihak disekitar obyek wisata tersebut sehingga banyaknya kunjungan wisatawan akan berpengaruh pada naiknya pendapatan desa. Solusi-solusi yang dimaksud dalam hal ini adalah strategi terkait dengan pengembangan objek wisata Telaga Biru agar dapat lebih berdaya saing dalam menarik wisatawan. Strategi sebagai bentuk upaya yang dilakukan untuk menciptakan dan melestarikan kawasan wisata dengan menggunakan dimensi-dimensi strategi yang menciptakan strategi yang sesuai dengan pengembangan kawasan obyek wisata Telaga Biru ini. Sehingga dengan demikian pemerintah desa Tanjung Alam dapat mengambil langkah yang strategis dari pilihan yang ada. 
Meskipun desa Tanjung Alam sangat berpotensi sebagai desa wisata, namun berbagai kendala yang harus dihadapi pemerintah desa Tanjung Alam dalam pengembangan wisata Telaga biru adalah infrastruktur yang kurang baik seperti kondisi jalan menuju Telaga Biru yang butuh perjuangan dengan kondisi curam dan dan berbatu, terbatasnya fasilitas pendukung seperti tempat penginapan yang belum tersedia yang akan mengurangi nilai (value) yang didapatkan wisatawan menjadi hambatan pelaksanaan kegiatan pariwisata di Desa Tanjung Alam. Wisatawan masih enggan untuk mengunjungi ataupun berlama-lama berada di desa ini karena segala sesuatu yang mungkin mereka butuhkan belum tersedia. Hal ini juga yang dapat memicu rendahnya angka wisatawan yang berkunjung ulang sebagai repeater tourist. Pada dasarnya pengembangan pariwisata di Desa Tanjung Alam sangat penting untuk dilakukan. Pengembangan pariwisata di Desa Tanjung Alam akan memberikan perubahan dan keberlangsungan baik jangka pendek maupun jangka panjang bagi masyarakat lokal dan pemerintah Merangin.

Adanya berbagai permasalahan tersebut maka pemerintah desa Tanjung mempunyai strategi untuk dalam mengatasi hal tersebut yaitu memanfaatkan Undang-Undang Nomor 6 Tahun 2014 sebagai langkah awal dalam pengembangan wisata Telaga biru dengan memamfaatkan dana desa untuk pengembangan potensi yang dimiliki yaitu sebagai desa wisata. Karena UU Nomor 6 Tahun 2014 beserta peraturan pelaksanaannya telah mengamanatkan pemerintah desa untuk lebih mandiri dalam mengelola pemerintahan dan berbagai sumber daya alam yang dimiliki, termasuk di dalamnya pengelolaan keuangan dan kekayaan milik desa seperti objek Telaga Biru yang terdapat di Desa Tanjung Alam ini. Sejalan dengan strategi tersebut di atas maka dalam pengelolaan sumber daya alam pedesaan melalui pelibatan masyarakat desa dalam mengelola dan memanfaatkan sumber daya alam di Desa Tanjung Alam maka pemerintahan desa Tanjung Alam telah megeluarkan Perdes No. 01/2016 dan Perkepdes 2017 No. 01/KDS tentang objek wisata Telaga Biru di kawasan hutan adat Desa Tanjung Alam. Adapun data statistik pengunjung objek wisata Telaga Biru dapat dilihat pada tabel 1.

Tabel 1. Data Statistik Pengunjung Objek Wisata Telaga Biru Desa Tanjung Alam

\begin{tabular}{ccc}
\hline Tahun & Jumlah Pengunjung (Orang) & Uang Masuk (Rp) \\
2014 & 600 & 3.500 .000 \\
2015 & 800 & 4.075 .000 \\
2016 & 900 & 6.010 .000 \\
2017 & 1010 & 14.000 .000 \\
\hline
\end{tabular}

Sumber : Kantor Desa Tanjung Alam, 2017

Strategi menjadi sangat penting bagi pengembangan sebuah organisasi/ perusahaan dalam rangka pencapaian tujuan, baik tujuan jangka pendek maupun jangka panjang. Analisa dalam pengembangan strategi berdasarkan dimensi-dimensi strategi yang digunakan yaitu Tujuan, Kebijakan dan Program. Oleh karena itu, penyusunan strategi merupakan langkah taktis yang bersifat sistematis dalam pencapaian tujuan organisasi. Berdasarkan uraian diatas maka penulis begitu tertarik untuk melakukan penelitian dengan judul : "Strategi Pemerintahan Desa Tanjung Alam Dalam Mengembangkan Wisata Telaga Biru (Studi Kasus Desa Tanjung Alam Kecamatan Jangkat Timur Kabupaten Merangin)". 


\section{Metode}

Dalam penelitian ini penulis menggunakan metode penelitian kualitatif. Penelitian kualitatif bertujuan untuk mengungkapkan informasi kualitatif sehingga lebih menekankan pada masalah proses dan makna dengan mendeskripsikan sesuatu masalah. Penelitian yang dilakukan bersifat Deskriptif yaitu untuk mengetahui atau menggambarkan kenyataan dari kejadian yang diteliti atau penelitian yang dilakukan terhadap variabel mandiri atau tunggal, yaitu tanpa membuat perbandingan atau menghubungkan dengan variabel lain. Sehingga memudahkan penulis untuk mendapatkan data yang objektif dalam rangka mengetahui dan memahami manajemen strategi pengembangan pariwisata Telaga Biru Desa Tajung Alam Kecamatan Jangkat Timur Kabupaten Merangin.

Dengan pendekatan ini diharapakan mampu menjaring realita di lapangan dengan mengumpulkan data secara langsung di lapangan melalui wawancara dokumentasi dan obsevasi.

\section{Teknik Pengumpulan Data}

Untuk memperoleh data-data yang dibutuhkan dalam penelitian ini digunakan berbagai teknik sebagai berikut :

\section{Wawancara}

Wawancara adalah percakapan dan tanya jawab yang diarahkan untuk mencapai tujuan tertentu. Dilakukan guna memperoleh informasi dan keterangan dari informan. Peneliti mengadakan tanya jawab dengan para informan untuk memperoleh data mengenai hal-hal yang ada kaitannya dengan masalah penelitian ini dalam hal melakukan wawancara digunakan pedoman pertanyaan yang disusun berdasarkan kepentingan masalah yang diteliti. Kelonggaran cara ini akan mampu mengorek kejujuran informan untuk memberikan informasi yang sebenarnya dalam pengembangan pariwisata Telaga Biru ini.

\section{Obsevasi}

Observasi adalah pengamatan dan pencatatan dengan sistematik fenomena-fenomena yang diselidiki. Observasi dilakukan dengan jalan formal maupun non formal. Metode ini mampu mengarahkan peneliti untuk mendapatkan sebanyak mungkin pengetahuan yang berkaitan dengan masalah penelitian yaitu Strategi pengembangan pariwisata yang merupakan berbagai gambaran strategi untuk pengembangan potensi pariwisata Telaga Biru. Strategi tersebut terbentuk dengan memanfaatkan sumber daya, dana/anggaran, sumber daya manusia, dan sarana dan prasarana yang dimiliki untuk melaksanakan pengembangan potensi pariwisata.

\section{Dokumentasi}

Dokumentasi adalah metode yang menggunakan data yang tersedia yang berupa data verbal maupun non verbal. Misalnya data yang terdapat pada surat-surat, jurnal, laporan-laporan dan sebagainya untuk kelengkapan data penelitian

\section{Teknik Pemilihan Informan}

Pada penelitian ini teknik penentuan informan yang digunakan adalah: Purposive Sampling. Purposive Sampling adalah teknik pengambilan sampel sumber data dengan pertimbangan tertentu, pertimbangan dalam hal ini yakni orang-orang yang memiliki kriteria dan dianggap paling tahu tentang apa yang kita harapkan dalam penelitian, atau mungkin dia sebagai penguasa sehingga akan memudahkan penelitian menjelajahi objek penelitian. 


\section{Jenis-Jenis Data}

Adapun jenis data yang akan digunakan dalam penelitian adalah data primer dan data sekunder.

\section{Data Primer}

Data primer adalah data yang diperoleh atau dikumpulkan langsung di lapangan oleh orang yang melakukan penelitian atau yang bersangkutan yang memerlukannya. Data primer juga disebut dengan data asli atau baru. Sumber data primer yang pertama yaitu responden, responden merupakan objek dari penelitian. Dari responden inilah, peneliti dapat mencari data yang dibutuhkan. Dalam penelitian ini adalah prangkat Desa Tanjung Alam.

Sementara itu sumber data yang kedua yaitu informan, informan merupakan sumber berupa orang, dari beberapa informan diharapkan dapat terungkap kata-kata dan tindakan yang diharapkan. Informan ini di pilih dari beberapa orang yang betul-betul dapat dipercaya mengetahui objek yang akan diteliti. Dalam penelitian ini yang dipilih sebagai informan adalah Tokoh masyarkat desa Tanjung Alam, Kepala desa serta perangkat desa Tanjung Alam Kecamatan Jangkat Timur Kabupaten Merangin yang bersangkut paut dengan pariwisata.

\section{Data sekunder}

Data sekunder adalah data yang diperoleh atau dikumpulkan oleh orang yang melakukan penelitian dari sumber-sumber yang telah ada. Sumber tertulis dapat di bagi atas sumber buku dan majalah ilmiah, sumber dari arsip, dokumen pribadi dan dokumen resmi, data ini biasanya dari perpustakaan atau laporan dari peneliti terdahulu. Data sekunder juga disebut dengan data tersedia. Untuk penelitian ini data di peroleh dari sumber tertulis, yaitu bersumber dari buku-buku atau literatur yang berkaitan dengan judul penelitian ini.

\section{Hasil dan Pembahasan}

\section{Strategi Pengembangan Pemerintahan desa Tanjung Alam}

Sebagaimana dengan metode yang digunakan dalam penelitian ini yaitu metode kualitatif yang menganalisis lebih mendalam terhadap data-data yang diperoleh. Data yang dimaksud dalam hal ini yaitu wawancara yang dilakukan pada pihak-pihak yang dianggap berkompeten terhadap permasalahan dalam fokus penelitian. Dalam hal ini adalah pengembangan obyek wisata pariwsata Telaga Biru di desa Tanjung Alam Kabupaten Merangin Kecamatan Jangkat Timur yang berfokus pada desa Tanjung Alam yang mempunyai tugas melaksanakan urusan pemerintahan, kepentingan masyarakat setempat berdasarkan prakarsa masyarakat, hak asal usul dan/atau hak tradisional yang diakui dan dihormati dalam sistem pemerintahan NKRI.

Selanjutnya hasil penelitian yang dilakukan penulis, akan dibagi berdasarkan fokus masalah yang dibahas terkait dengan teori yang digunakan yaitu Dimensi Strategi menurut Henry Mintzberg, Joseph Lampel, James Brian Quinn, dan Sumantra Ghoshal (2003) dalam buku The Strategy Process yaitu: Tujuan, Kebijakan dan Program yang akan menghasilkan suatu strategi. Pemerintahan Desa Tanjung Alam terhadap pengembangan kawasan Telaga Biru adalalah Strategi sebagai Rencana, karena Kepala Desa Tanjung Alam selaku yang bertanggung jawab penuh terhadap segala urusan kebudayaan dan kepariwisataan di desa Tanjung Alam ini, yang menetapkan arah organisasi menjadi lebih baik dengan berbagai perencanaan yang disusun secara matang dan segala Tujuan, Kebijakan dan Program yang dilakukan Pemerintahan Desa Tanjung Alam yang dikembangkan secara sadar dan sengaja sesuai dengan pengertian Strategi sebagai Rencana yakni : Strategi adalah rencana, semacam sadar dimaksudkan yang meliputi tindakan, pedoman (atau pedoman yang ditetapkan) untuk menangani situasi.

Dengan definisi ini, strategi memiliki dua karakteristik penting: mereka dibuat sebelum tindakan yang menerapkan, dan mereka dikembangkan secara sadar dan sengaja. Sebagai rencana, strategi berkaitan dengan bagaimana pemimpin mencoba untuk menetapkan arah untuk organisasi, untuk mengatur mereka pada tindakan yang telah ditentukan. Adapun strategi tersebut adalah sebagai berikut: 


\section{Penyediaan Sarana dan Prasarana Wisata Telaga Biru}

Kebijakan yang akan dilakukan pemerintahan desa Tanjung Alam dalam mengembangkan objek wisata Telaga Biru adalah penyediaan sarana dan prasaran atau faktor fasilitas dan infrastruktur yaitu jalan utama menuju objek wisata Telaga Biru. Fasilitas dan infrastruktur menuju objek wisata Telaga biru termasuk kedalam Accessibility atau aksesibilitas, seperti akses jalan raya, ketersediaan sarana transportasi dan rambu-rambu penunjuk jalan merupakan bagian aspek pendukung kelancaran menuju objek wisata tersebut. Ada beberapa cara menuju objek wisata Telaga Biru yaitu berjalan kaki yang memakan waktu selama 7 jam dan menggunakan kendaraan roda 2 yang hanya memakan waktu waktu 3 jam dari desa Tanjung Alam.kualitas jalan menuju arah Telaga Biru sampai saat yang belum memadai dan masih belum beraspal serta tanda jalan atau rambu-rambu petunjuk arah menuju objek wisata belum ada sehingga hal ini menjadi kendala yang harus secepatnya dibangun mengingat bertambahnya peminat atau pengunjung objek wisata Telaga Biru. Berdasarkan hasil wawancara dengan kepala desa Tanjung Alam Bapak Pahlepi Sahreza, ketika ditanya tentang kebijakan-kebijakan yang apa yang dikeluarkan pemerintah desa dalam pengembangan objek wisata Telaga Biru.

Adanya akses yang mudah menuju lokasi wisata tentu akan meningkatkan nilai tambah tersendiri selain beberapa kemudahan atau keunggulan potensi alam yang sudah dimiliki oleh desa wisata tersebut. Keberhasilan dalam proses pengembangan suatu wisata tidak dapat dilepaskan dari adanya campur tangan sebuah lembaga atau institusi lokal yang mengelola wisata tersebut. Institusi lokal ini yang menjadi perpanjangan tangan dari berbagai stake holder yang terhubung langsung dan tak langsung dengan semua aktivitas pariwisata di desa.

Keseluruhan yang dimaksud adalah pengembangan objek wisata yang dipandang sebagai sesuatu yang utuh dan bukan merupakan kesatuan dari bagian- bagian yang terpisah. Langkah awal yang dilakukan pemerintahan desa Tanjung Alam dalam pengembangan objek wisata Telaga Biru secara fisik adalah dengan membuka akses jalan beserta rambu jalan sebagai petunjuk arah sehingga pengunjung tidak merasa gelisah ataupun was-was sampai ke lokasi Telaga Biru. Pengembangan secara keseluruhan yang pengerjaan awalnya tefokus pada satu titik yaitu akses jalan menuju objek wisata Telaga Biru dan pada saat pembangunan akses jalan berlangsung pemerintahan desa juga akan melakukan pengembangan terhadap sumber daya manusia yaitu terhadap masyarakat sadar wisata disekitar desa Tanjung Alam serta para pemuda dengan melakukan pelatihan-pelatihan.

\section{Tambahan Promosi}

Selain sarana dan infrastruktur kebijakan yang akan dilakukan adalah promosi yang sangat berpengaruh bagi pengembangan objek wisata Telaga Biru, faktor promosi juga memiliki pengaruh yang cukup besar bagi tercapainya pembangungan desa wisata yang mampu meningkatkan perekonomian masyarakatnya. Promosi merupakan upaya untuk memberitahukan atau menawarkan produk maupun jasa dengan tujuan untuk menarik calon konsumen untuk membeli atau mengonsumsinya. Manajemen promosi yang baik dan benar akan menjadikan produk maupun jasa tersebut menarik dan mampu membuat konsumennya merasa menginginkannya. Salah satu indikator dari kebijakan pengembangan pariwisata adalah promosi sebagai pelaksanaan upaya pemasaran yang selaras dan terpadu. Pemasaran merupakan kegiatan yang sangat penting, sehingga pembeli mendapat keuntungan maksimal dengan resiko sekecil-kecilnya. Selain itu juga ada aksesbilitas, sebagai pengembangan lintas sektoral, dan pengembangan kawasan pariwisata dan produk pariwisata.

Promosi merupakan salah satu faktor penentu keberhasilan suatu program pemasaran. Bagaimanapun berkualitasnya suatu produk, bila konsumen belum pernah mendengarnya dan tidak yakin bahwa produk itu akan berguna bagi mereka, maka mereka tidak akan pernah membelinya. Pada hakikatnya promosi adalah suatu bentuk komunikasi pemasaran. Sedangkan komunikasi pemasaran itu sendiri adalah aktivitas pemasaran yang berusaha menyebarkan informasi, mempengaruhi/ membujuk, dan mengingatkan pasar sasaran atas perusahaan dan produknya agar bersedia menerima, membeli dan loyal pada produk yang ditawarkan perusahaan yang bersangkutan 


\section{Pembentukan Pengurus Tetap}

Wisata Telaga Biru adalah aset dan program yang di prioritas pengembangannya oleh pemerintahan desa Tanjung Alam namun pengelolaan wisata Telaga biru sangatlah lemah, hal ini dapat dilihat dari perlengkapan maupun fasilitas yang tersedia belum tampak keberadaannya. Meskipun pengelolaan yang lemah namun pada dasarnya wisata Telaga Biru sangat berarti bagi masyarakat di desa Tanjung Alam dan memberikan dorongan yang berarti untuk pembangunan desa Tanjung Alam kedepannya. Prinsip pengembangan desa wisata adalah sebagai salah satu produk wisata alternatif yang dapat memberikan dorongan bagi pembangunan pedesaan yang berkelanjutan serta memiliki prinsipprinsip pengelolaan antara lain, ialah: (1) memanfaatkan sarana dan prasarana masyarakat setempat, (2) menguntungkan masyarakat setempat, (3) berskala kecil untuk memudahkan terjalinnya hubungan timbal balik dengan masyarakat setempat, (4) melibatkan masyarakat setempat, dan (5) menerapkan pengembangan produk wisata pedesaan,

Pengembangan wisata Telaga Biru merupakan keinginan masyarakat Desa Tanjung dan telah disepakati oleh pemerintahan desa sesuai prosedur yang berlaku yaitu dengan melakukan musyawarah desa dan telah dicatat oleh sekretaris desa meskipun belum diundangkan dan telah disetujui oleh pemerintahan desa dan BPD desa Tanjung Alam. Sehingga dengan musyawarah desa dan atas kesepakatan bersama tersebut pengembangan Telaga Biru menjadi Rencana jangka menengah desa Tanjung Alam. Untuk mewujudkan keinginan masyarakat tersebut maka peran pemerintahan desa dalam mengembangkan obyek wisata merupakan syarat mutlak dalam memajukan potensi wisata yang dimiliki desa tersebut dan membutuhkan strategi sehingga dengan strategi yang direncanakan dapat bermanfaat bagi masyarakat sekitar baik secara ekonomi, sosial maupun budaya dan menjadi modal awal dalam menambah Pendapatan Asli Desa (PADes) dari sektor pariwisata

\section{Koordinasi Dengan Sektor Pendukung Pariwisata.}

Adapun program-program yang akan dilakukan pemerintahan desa Tanjung Alam dalam bidang kepariwisataan salah satunya adalah koordinasi dengan sektor pariwisata. Pengembangan wisata Telaga Biru di Desa Tanjung Alam mengusung konsep tradisional dengan melibatkan masyarakat lokal untuk berpartisipasi langsung sebagai manajemen pengelola. Pada tahap perintisan wisata Telaga Biru, peran Pemerintah Desa sangatlah menetukan dalam mencapai keberhasilan. Pemerintah Desa Tanjung Alam merumuskan strategi pengembangan wisata Telaga Biru dengan meningkatkan kapasitas (capacity building) dari seluruh elemen stakeholder yang terlibat baik itu Pemerintah Desa, organisasi lokal dan masyarakat lokal. Pengembangan kapasitas dan kemampuan (capacity building) yang digagas oleh Pemerintah Desa Tanjung Alam adalah ingin meningkatkan kinerja secara optimal untuk menunjang pencapaian target pembangunan ekonomi, pembenahan SDM, meningkatkan kemampuan individu dalam rangka mewujudkan pengembangan wisata Tanjung Alam berbasis masyarakat.

\section{Pelaksanaan Promosi Pariwisata Nusantara Terutama Di Dalam Negeri.}

Peranan pemasaran pariwisata dapat meningkatkan pengetahuan dan kesadaran pemangku kepentingan pariwisata, terutama pangsa pasar utama terhadap upaya pelestarian produk-produk wisata secara berkelanjutan. Strategi pemasaran menyediakan kerangka kordinasi, sehingga para pemangku kepentingan pariwisata yakni Dinas Pariwisata yang bertanggung jawab terhadap objek-objek wisata akan memiliki arah yang sama dalam upaya pengembangan mengelola destinasi dan mempromosikan pariwisata di daerahnya

Meskipun dari pihak pemerintahan desa sendiri belum pernah melakukan promosi namun pada situs-situs tertentu secara tidak langsung sudah mempromosikan tentang objek wisata Tanjung Alam ini. Seperti yang diungkapkan oleh salah satu yang menyatakan bahwa selama perjalanan mata kita akan disuguhkan dengan pemandangan perbukitan, persawahan yang menghampar luas ditambah bunyi gemercik air dari aliran irigasi sawah serta kebun kopi yang berada disepanjang jalan yang dilengkapi pondok peristirahatan petani yang bisa digunakan oleh wisatawan untuk beristirahat saat hendak mengunjungi telagabiru dikatakan bahwa selama perjalanan sudah ada. 
Vol 1, No 1, Juni 2019, pp. 40-51

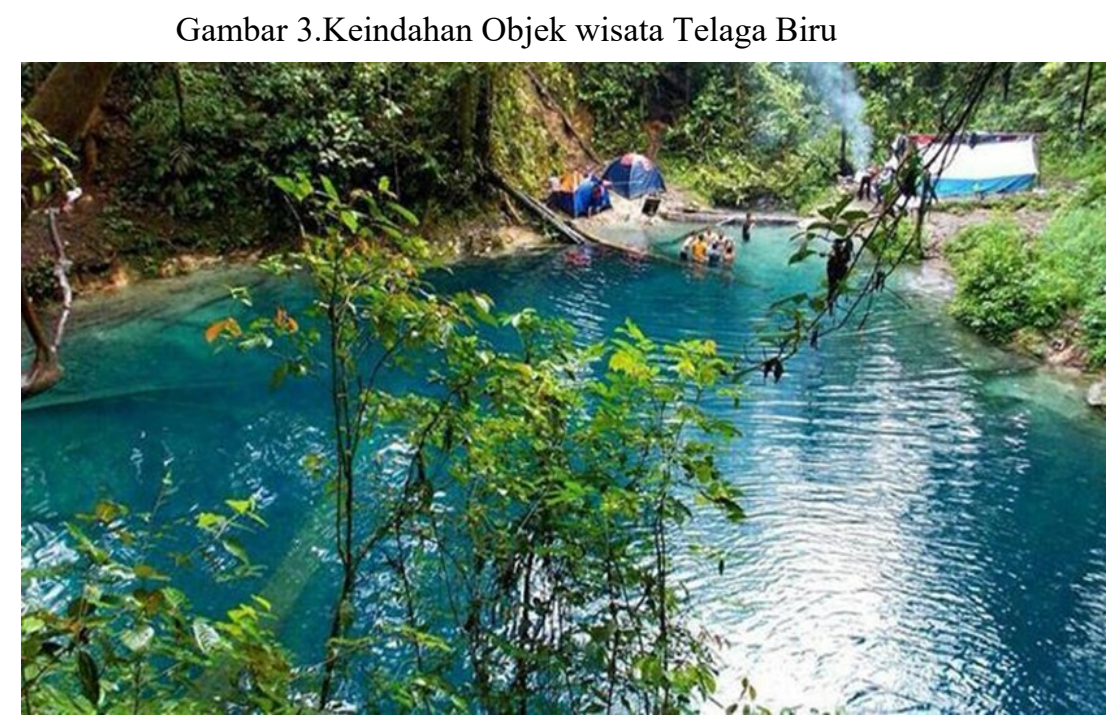

Sumber : https://www.vebma.com

Berdasarkan uraian tentang pelaksanaan promosi pariwisata nusantara terutama di dalam negeri maka menurut penulis itu, pemerintah perlu menggencarkan forum-forum dialog dan komunikasi antar sesama pelaku industri dan budaya agar dapat lebih mudah menemukan strategi guna mengidentifikasi potensi yang masih bisa dikembangkan guna meningkatkan kualitas pariwisata di Kecamatan Jangkat khususnya Telaga Biru. Suatu hal yang sering dijumpai bahwa ide-ide serta gagasan cemerlang biasanya hadir dalam dialog-dialog serta forum komunikasi tak terkecuali terhadap strategi pengembangan obyek wisata.

\section{Pelatihan Pemandu Wisata}

Pelatihan terhadap pemandu wisata adalah salah kegiatan pokok dalam program pengembangan pemasaran Pariwisata. Sumber daya manusia merupakan salah satu modal dasar dalam upaya pengembangan pariwisata. Sumber daya manusia dalam bidang kepariwisataan harus memiliki keahlian dan memiliki keterampilan untuk memberikan pelayanan pariwisata serta menangani berbagai permasalahan kepariwisataan dan berbagai persoalan yang ada. Berhasilnya suatu pembangunan dan pengembangan sektor pariwisata di desa Tanjung Alam juga tergantung pada kemampuan para pelaksana yang bertugas pada tempat-tempat daerah tujuan wisata maupun aparat pelaksana pengembangan sektor pariwisata.

Salah satu strategi utama yang disusun oleh pemerintahan desa Tanjung Alam adalah Pengembangan Sumber Daya Manusia dimana poin penting dalam pengembangan sumber daya manusia yang dimaksud itu diantaranya : pengembangan akan profesionalisme sumber daya manusia dengan mengadakan pelatihan dan pendidikan.

Pemberdayaan masyarakat dalam konteks pengembangan pariwisata merupakan upaya penguatan dan peningkatan kapasitas, peran dan inisiatif masyarakat sebagai salah satu stakeholder penting di luar unsur pemerintah dan swasta, untuk dapat berpartisipasi dan beran aktif dan strategi sebagai subyek maupun sebagai penerima manfaat dalam pengembangan kepariwisataan secara berkelanjutan. Mengingat hal tersebut di atas, maka pemerintahan desa telah membuat kebijakan meskipun belum diundangkan tapi sudah tercatat sebagai Rencana Pembangunan Jangka Menengah (RPJM) desa Tanjung Alam. Pengembangan obyek wisatanya secara bertahap dan menyeluruh dengan fokus terhadap pengembangan satu obyek wisata dan selanjutnya melangkah ke pengembangan obyek wisata itu sendiri yaitu berupa perlengkapan-perlengkapan wisata seperti WC, atraksi wisata, tempat penginapan, dan prasarana wisata lainnya. 


\section{Kendala Pemerintahan Desa Tanjung Alam Dalam Pengembangan Wisata Telaga Biru}

Dari hal tersebut diatas dapat dipaparkan bahwa kendala yang dihadapi pemerintahan desa Tanjung Alam dalam mengembangkan wisata Tanjung Alam adalah:

\section{Keterbatasan dana}

Pengembangan wisata Telaga Biru sebagai potensi desa Tanjung Alam selama ini masih terkendala oleh dana yang dijadikan sebagai sumber utama pembangunan infrastruktur seperti akses jalan raya menuju tempat wisata serta untuk melengkapi kegiatan sarana prasarana yang dapat mendukung kegiatan pengelolaan wisata secara efektif dan efisien. Selama ini dana diperoleh hanya dari dana desa, dana itupun hanya untuk ifrastruktur jalan menuju lokasi dan pembangunannya juga dilakukan bertahap. Sedangkan dana untuk fisilitas wisata sendiri diperoleh dari sumbangan sukarelawan masyarakat melalui kegiatan sosial, pihak swasata yang menyalurkan dana melalui program kegiatan maupun proyek kepdulian terhadap kelestarian lingkungan (corporate social responsibility).

2. Rendahnya kualitas SDM (sumber daya manusia) pengelola

Rendahnya kualitas SDM (sumber daya manusia) pengelola menjadi kendala pengembangan wisata Telaga Biru sebagai potensi desa Tanjung Alam. Hal ini disebabkan sebagian besar masyarakat di Desa Tanjung Alam hanya berpendidikan sekolah dasar. Sehingga pelaksanaan programprogram kegiatan harus dilakukan dengan sosialisasi dan penyuluhan yang membutuhkan waktu lama.

Salah satu strategi utama yang disusun oleh pemerintahan desa Tanjung Alam adalah strategi pengembangan Sumber Daya Manusia dimana poin penting dalam pengembangan sumber daya manusia yang dimaksud itu diantaranya : Pengembangan akan profesionalisme sumber daya manusia pengelola dengan mengadakan pelatihan dan pendidikan, namun rencana ini belum terlaksana

3. Peran Pemerintah Daerah Kabupaten Merangin yang belum aktif dalam mendukung penyediaan sarana dan prasarana kegiatan wisata serta belum memberikan bantuan secara finansial yang dirintis oleh Pemerintah Desa Tanjung Alam.

Peran Pemerintah Daerah Merangin yang masih pasif ini sangat menghambat pembangunan wisata Tanjung Alam. Padahal jika ditinjau, pengembangan wisata Tanjung Alam memerlukan rencana strategis yang menghubungkan intruksi kepariwisataan secara menyeluruh. Hal ini karena sebagaimana hasil wawancara dengan kepala desa Tanjung Alam.

"kalau menyinggung pariwisata ya... pihak dari Kabupaten sih tidak ada konfirmasi lebih lanjut sampai saat ini, sehingga kita jalankan aja rencana dan program kita,... semoga wisata Telaga biru semakin ramai dan pemerintahan Kabupaten sehingga pihak yang bersangkutan dari pihak Kabupaten tergugah dan kita berharap kedepannya ada bantuan untuk pariwisata Telaga biru ini”.

Berdasarkan hal tersebut jelas bahwa kurang aktifnya atau tidak adanya kejelasan peran pemerintahan Kabupaten Daerah Kabupaten Merangin dalam pengembangan wisata Telaga Biru tidak menyurutkan langkah pemerintahan desa Tanjung Alam dalam mengembangkan objek wisata Telaga Biru dengan harapan kedepannya, pemerintahan Daerah Kabupaten Merangin tergugah untuk ikut serta dalam pengembangan wisata yang ada di desa Tanjung Alam terutama objek wisata Tanjung Alam. 


\section{Implementasi Strategi sebagai Rencana}

Beberapa implementasi strategi yang dilakukan Perintahan desa Tanjung Alam terkait strategi yang teridentifikasi yaitu Strategi sebagai Rencana dengan melihat potensi dari obyek wisata Talaga Biru adalah :

1. Pengembangan yang dilakukan terfokus pada satu titik agar kiranya pengembangan yang dilakukan akan terlihat hasilnya.

2. Melibatkan semua elemen-elemen yang terkait dengan pengembangan yang akan dilakukan sehingga pengembangan tersebut dapat kita lakukan dengan membuahkan hasil maksimal yang diharapkan bersama.

3. Mengidentifikasi secara menyeluruh terhadap obyek yang akan dikembangkan agar dapat menyusun segala perencanaan dengan sebaik-baiknya.

4. Melakukan pelatihan-pelatihan baik pemandu wisata, pelaku wisata dan pengelolah wisata.

5. Koordinasi yang terus dilakukan kepada pemerintah dan warga sekitar kawasan obyek wisata.

Adapun sumber daya yang mendukung pengembangan kawasan obyek wisata Telaga Biru ini adalah sebagai berikut:

1. Keindahan alam yang masih terbilang alami yang dikelilingi pohon-pohon yang rimbun dan suasana yang begitu menyejukkan.

2. Sarana dan prasarana yang sudah ada seperti jalan setapak, akses jalan dan bangunan-bangunan yang lain.

3. Keterlibatan semua elemen-elemen yang dapat menunjang pengembangan kawasan obyek wisata Telaga Biru

\section{Kesimpulan}

Berdasarkan hasil penelitian dan pembahasan penulis pada uraian sebelumnya maka dapat ditarik kesimpulan sebagai berikut : terkait dengan dimensi-dimensi strategi yakni: Tujuan, Kebijakan dan Program yang dilakukan Pemerintahan Desa termasuk ke dalam Strategi. Adapun strategi pemerintahan desa Tanjung Alam dalam pengembangan wisata Telaga Biru yaitu penyediaan sarana dan prasarana wisata telaga biru, rencana tambahan promosi, pembentukan pengurus tetap, koordinasi dengan sektor pendukung pariwisata, pelaksanaan promosi pariwisata nusantara terutama di dalam negeri dan pelatihan pemandu wisata. Dan kendala yang dihadapi pemerintahan desa Tanjung Alam dalam pengembangan wisata Tanjung Alam adalah keterbatasan dana, rendahnya kualitas SDM (sumber daya manusia) pengelola dan Peran Pemerintah Daerah Kabupaten Merangin yang belum aktif dalam mendukung penyediaan sarana dan prasarana kegiatan wisata. 


\section{Daftar Pustaka}

\section{Buku - Buku :}

[1] Bracker, J. 1980. The Historical Development of the Strategic Mnagement Concept. Academy of Management Review, 5(2).

[2] Hadiwijoyo, Suryo Sakti. 2012. Perencanaan Pariwisata Perdesaan Berbasis Masyarakat; Sebuah Pendekatan Konsep. Yogyakarta: Graha Ilmu

[3] Hasan Ikbal. 2002 Metodologi Penelitian Kualitatif. Renaja Rosdakarya. Bandung.

[4] Koentjaraningrat, 1980. Metode-Metode Penelitian Masyarakat. Gramedia. Jakarta.

[5] Mintzberg, Henry. dkk, 2003. The Strategy Process. Edisi Keempat. New Jersey: Upper Saddle River

[6] Pendit, Nyoman S. 2002. Ilmu Pariwisata Sebuah Pengantar Perdana. Jakarta: Pradnya Paramita

[7] Salusu, J. 2015. Pengambilan Keputusan Stratejik Untuk Organisasi Publik dan Organisasi Nonprof it. Jakarta: Gramedia Widiasarana Indonesia.

[8] Siagian, Sondang P, 2003. Manajemen Stratejik. Jakarta: Bumi Aksara

[9] Soekadijo. 1996. Anatomi Pariwisata (Memahami Pariwisata Sebagai Systemic Linkage). Jakarta : Gramedia

[10] Soewantoro, Gamal. 1997. Dasar-Dasar Pariwisata. Yogyakarta

[11] Spillane, James.1993. Ekonomi Pariwisata, Sejarah dan prospeknya. Yogyakarta: Kanisius.

[12] Sugiyono. 2009. Metode Penelitian Kualitatif dan R \& D. Bandung : Alfa Beta

[13] Sutrisno, Hadi. 1992. Metodologi Resarch. Andi Ofset : Yogyakarta.

[14] Yoeti, Oka, A. 2008 Perencanaaan dan Pengembangan Pariwisata. Jakarta, Pradaya Pratama.

[15] Yoeti, Oka. A. 2006. Perencanaan Strategis Pemasaran Daerah Tujuan Wisata. Jakarta : PT Pradaya Paramita.

\section{Peraturan Perundang-Undangan}

[1] Undang-Undang nomor 10 Tahun 2009 tentang kepariwisataan

[2] Undang-undang No 11 Tahun 2009, tentang Kesejahteraan Masyarakat

[3] Undang-Undang Nomor 6 Tahun 2014 Tentang Desa Perdes No. 01/2016 dan Perkepdes 2017 No. 01/KDS tentang objek wisata Telaga Biru di hutan adat Desa Tanjung Alam

\section{Internet :}

[1] http://www.thejambitimes.com/2017/04/telaga-biru-di-merangin.html

[2] https://tourismbali.wordpress.com/2011/04/10/dimensi-ekonomi-pariwisata-kajian-terhadap-dampakekonomi-dan-refleksi-dampak-pariwisata-terhadap-pembangunan-ekonomi-provinsi-bali/

[3] http://www.definisimenurutparaahli.com/pengertian-wisata/ diakses tanggal, 5 Oktober 2017

\section{Rujukan Skripsi :}

[1] Guswan, 2015. Strategi Pengembangan Pariwisata Kawasan Tanjung Bira Pada Dinas KebudayaanDan Pariwisata Kabupaten Bulukumba. 